\title{
Importance of the Solvation Degree of Peptide-Resin Beads for Amine Groups Determination by the Picric Acid Method
}

\author{
Eduardo M. Cilli, Guita N. Jubilut, Suely C. F. Ribeiro, Eliandre Oliveira and Clovis R. Nakaie*
}

Departamento de Biofísica, Universidade Federal de São Paulo, Rua 3 de Maio, 100, 04044-020, São Paulo-SP, Brazil

\begin{abstract}
O clássico e importante método do ácido pícrico, usado nas áreas de bioquímica e química de polímeros para a quantificação de grupos aminos, foi escolhido neste trabalho como modelo para investigar a importância do grau de solvatação de grãos poliméricos durante o protocolo analítico. Verificou-se que este método, proposto há cerca de três décadas atrás, falha na quantificação de grupos amino de peptidil-resinas contendo sequiência agregante e polar. Isto ocorre devido à solvatação insuficiente dos grãos quando apenas o $\mathrm{CH}_{2} \mathrm{Cl}_{2}$ é utilizado na etapa de ligação do ânion picrato e na subsequente etapa de lavagem. Demonstrou-se que a utilização nestas etapas, de soluções de $\mathrm{CH}_{2} \mathrm{Cl}_{2} / \mathrm{DMF}$ (dimetilformamida) e de $\mathrm{CH}_{2} \mathrm{Cl}_{2} / \mathrm{EtOH}$ permite uma determinação correta dos grupos amínicos de peptídil-resinas. Além da importância em si para o método da síntese de peptídeos em fase sólida, estes resultados representam também a primeira comprovação experimental da correlação quantitativa existente entre o grau de solvatação e a eficiência de um método analítico efetuado em grãos de resinas.
\end{abstract}

\begin{abstract}
The classic and important picric acid method used in polymers biochemical and chemical fields of polymers for amine group quantification was chosen in this work as a model for evaluating the influence of the resin bead solvation during an analytical procedure. It was observed that this method, proposed almost three decades ago, failed to quantify amine groups of peptidyl-resin containing aggregating and polar sequence. This was due to inefficient solvation of resin beads when only $\mathrm{CH}_{2} \mathrm{Cl}_{2}$ was used for picrate anion binding and subsequent washing steps. It was demonstrated that the use of $\mathrm{CH}_{2} \mathrm{Cl}_{2} / \mathrm{DMF}$ (dimethylformamide) and $\mathrm{CH}_{2} \mathrm{Cl}_{2} / \mathrm{EtOH}$ solutions during these steps allows correct determination of peptidyl-resin amine groups. Besides the importance for the solid phase peptide synthesis methodology itself, these findings also represent the first quantitative demonstration of the relationship between solvation degree and the efficiency of a polymer-supported analytical method.
\end{abstract}

Keywords: picric acid method, peptide synthesis, polymer, polarity, resin

\section{Introduction}

It is well recognized that the success of any polymersupported process depends upon the solvation degree of its polymeric matrix. This is particularly true for solid phase peptide synthesis ${ }^{1,2}$ where the better the solvation of resin beads, the higher the yield of the synthesis ${ }^{3,4}$. In an attempt to further investigate this issue, we have proposed rules which might govern solvation of peptidyl-polymers varying the nature and the amount of peptide chains ${ }^{5}$. Based upon the correlation between solvation data of different peptideresins (taken as solute models) in 28 solvent systems, which encompass entirely the polarity scale, it was also possible to propose, in this report, the (AN+DN) summation term as a novel polarity parameter. The $\mathrm{AN}$ and $\mathrm{DN}$ values ${ }^{6}$ represent the electron acceptor and donor properties of the solvent,

*e-mail: clovis.biof@epm.br respectively and this alternative polarity term will be further used in the present report.

Spectroscopic methods have also been used for solvation studies including Fourier-transform infra-red ${ }^{7}$, nuclear magnetic ${ }^{8}$ and electron $\operatorname{spin}^{9,10}$ resonance methods for assessment of resin-bound peptide chains motions, using in the latter, a labeling strategy with a special paramagnetic amino acid-type probe ${ }^{11}$. This effort in improving the polymer solvation knowledge has also recently led us to demonstrate that benzhydrylamine-resin (BHAR) ${ }^{12}$, a phenylmethylamine group-containing copolymer of styrene$1 \%$-divinilbenzene, so far used as the solid support for peptide synthesis, can be alternatively employed as a novel anion exchange resin for liquid chormatography ${ }^{13,14}$.

Hence, aiming to better evaluate the importance of polymer solvation characteristics, the present work describes, for the first time, the quantitative influence of the bead solvation upon the effectiveness of a resin-supported 
analytical method. Because it is considered simple, nondestructive and very accurate, the picric acid method ${ }^{15,16}$ was chosen for this investigation. Besides its application for quantification of resin-bound amine groups in the polymer field, this analytical procedure, similarly to the ninhydrin procedure ${ }^{17}$, is also very useful for monitoring the critical amino acid coupling or peptide $\alpha$-amine group deprotection reactions during the stepwise solid phase peptide synthesis cycles ${ }^{1,2}$. The picric acid method is based on the 1:1 picrate-ammonium salt formation in the resin, after treatment with the picric acid. After exhaustive washing, the resin-bound picrate anion is usually eluted with $10 \%$ triethylamine (TEA) $/ \mathrm{CH}_{2} \mathrm{Cl}_{2}$ and this picrate salt is spectrophotometrically measured at $358 \mathrm{~nm}$ using a molar absorptivity of $14.500 \mathrm{dm}^{3} \mathrm{~mol}^{-1} \mathrm{~cm}^{-1}$ after dilution of the eluent with $\mathrm{EtOH}$ (more than $90 \%, \mathrm{v} / \mathrm{v})^{15}$. As only the apolar $\mathrm{CH}_{2} \mathrm{Cl}_{2}$ is used in most steps of the original picric acid method, we envisioned that a peptidyl-resin which does not swell appropriately in $\mathrm{CH}_{2} \mathrm{Cl}_{2}$ might be taken as model for demonstrating the exact contribution of the bead solvation degree on the efficacy of solid-supported analytical method.

\section{Experimental}

\section{Materials}

All amino acids, except Gly, are of the L-configuration. $\mathrm{N}$ - $\alpha$-tert-butyloxycarbonyl (Boc)-Asn, and -Ile were purchased from Bachem, Torrance, CA. The highly substituted $2.6 \mathrm{mmol} \mathrm{g}^{-1}$ BHAR batch was synthesized according to previous report ${ }^{18}$. Solvents and reagents were purchased from Aldrich or Sigma Co. Triethylamine (TEA) and diisoproprylethylamine were distilled over ninhydrin and dimethylformamide (DMF), over $\mathrm{P}_{2} \mathrm{O}_{5}$ and ninhydrin, under reduced pressure. All solvents used for swelling studies were HPLC grade.

\section{Peptide synthesis}

The peptides were synthesized manually accordingly to the standard Merrifield Boc/Bz strategy ${ }^{1}$. Briefly, the $\alpha$-amino group deprotection and neutralization steps were performed in trifluoroacetic acid (TFA), $30 \%(\mathrm{v} / \mathrm{v})$ in $\mathrm{CH}_{2} \mathrm{Cl}_{2}$ and TEA, $10 \%(\mathrm{v} / \mathrm{v})$ in $\mathrm{CH}_{2} \mathrm{Cl}_{2}$, respectively. The scale of synthesis was $0.2 \mathrm{mmol}$ and all Boc-amino acids were coupled in DMF with benzotriazole-1-yl-oxy-tris(dimethylamino)-phosphonium hexafluorophosphate (BOP) in the presence of $\mathrm{N}$-hydroxybenzotriazole (HOBt) and diisopropylethylamine (with a 4- and 5- fold excess over the amino component in the resin, respectively). Boc-Asn was coupled in $\mathrm{CH}_{2} \mathrm{Cl}_{2} / \mathrm{DMF}$ (1:1) using diisopropylcarbodiimide and $\mathrm{HOBt}$ as acylating reagents (3-fold excess). After double coupling with a two-hour reaction time each, the qualitative ninhydrin test ${ }^{19}$ was carried out to estimate the completeness of the reaction.

\section{Swelling measurement of beads}

Before use in peptidyl-resin synthesis and microscopic measurement of bead sizes, the amino protonated BHAR batches ( $\mathrm{Cl}^{-}$form) were exhaustively sized by the suspension in $\mathrm{CH}_{2} \mathrm{Cl}_{2}, \mathrm{EtOH}$ and sifted in pore metal sieves to lower the standard deviations of resin diameters to about $4 \% 18$. From 150 to 200 dry and swollen beads of each resin, allowed to equilibrate overnight, were spread over a microscope slide and measured directly at low magnification. Since the sizes in a sample of beads are not normally but log-normally distributed, the central value and the distribution of the particle diameters were estimated by the more accurate geometric mean values and geometric standard deviations. ${ }^{20}$ Resins were dried in vacuo using an Abderhalden-type apparatus with $\mathrm{MeOH}$ refluxing.

\section{Results and Discussion}

The ING [(72-74)-acyl carrier protein] fragment, known to be aggregating ${ }^{21}$ and also very polar according to a previous hydrophobic scale 22 was selected as the model of peptidyl-resin which does not present good solvation in $\mathrm{CH}_{2} \mathrm{Cl}_{2}$ if synthesized in highly substituted resins (2.6 mmol g-1 BHAR). Earlier results, ${ }^{5,10}$ with this peptidylresin have shown that when its amine group extremity is in unprotonated form (after alkaline treatment), only $31 \%$ of its total swollen bead volume is occupied by $\mathrm{CH}_{2} \mathrm{Cl}_{2}$ against $83 \%$ measured in the polar aprotic DMF.

Table 1 summarizes the results of four experimental variations applied for the picric acid method protocol, each one carried out with the same amount of the ING-BHAR containing a total of $0.363 \mathrm{mmol}$ of amine groups, previously determined with amino acid analysis. Protocol 1 shows the result obtained with the original picrate method where $\mathrm{CH}_{2} \mathrm{Cl}_{2}$ was used as the solvent for all steps of the procedure. The final amount of measured amine groups $(0.108 \mathrm{mmol})$ was significantly lower than expected, thus suggesting that the failure in this standard protocol might be due to an incomplete solvation of the peptidyl-resin in some steps of the method.

To help interpreting this result, the Table 2 displays for comparison, the complete microscopic swelling data of ING-BHAR containing its amine groups in unprotonated and protonated (picrate salt) forms. The polarity values of $\mathrm{CH}_{2} \mathrm{Cl}_{2}$, its 1:1 mixture with DMF and EtOH, estimated by the $(\mathrm{AN}+\mathrm{DN})$ scale $^{5}$ are also included in this table. The calculated percentage of total bead volume occupied by 
$\mathrm{CH}_{2} \mathrm{Cl}_{2}$ decreased appreciably from $31 \%$ to only $6 \%$ when its amine groups are transformed from unprotonated to protonated form, thus indicating that the lower amount of amine group measured with protocol 1 may be at least in part, due to the strong shrinking of peptidyl-resin beads during the picrate binding step carried out in $\mathrm{CH}_{2} \mathrm{Cl}_{2}$.

Noticeably, the result obtained with protocol 2 in Table 1 seems to confirm this hypothesis as the simple $\mathrm{CH}_{2} \mathrm{Cl}_{2}$ substitution with 1:1 $\mathrm{CH}_{2} \mathrm{Cl}_{2} / \mathrm{DMF}$ increased the amount of measured picrate groups removed from the resin. The resin swelling in this more polar mixed solvent, characterized by $(\mathrm{AN}+\mathrm{DN})$ value of 32 against 21.4 for $\mathrm{CH}_{2} \mathrm{Cl}_{2}$, increased from $6 \%$ to $73 \%$, as shown in Table 2 . However, despite of the improvement in this second protocol, the amount of measured ammonium groups $(0.392 \mathrm{mmol})$ was now slightly higher than the correct value $(0.363 \mathrm{mmol})$. One explanation for this result might be due to the low solvation of the picrateresin component but now at the washing step made solely in $\mathrm{CH}_{2} \mathrm{Cl}_{2}$, just after binding of the chromophore. This unfavorable swelling condition may induce incomplete release of excess unbounded picrate anion dispersed throughout the peptide-resin matrix, thus increasing slightly the measured ammonium group content of the experiment in the protocol 2.
In the light of this hypothesis, replacement of $\mathrm{CH}_{2} \mathrm{Cl}_{2}$ for $1: 1 \mathrm{CH}_{2} \mathrm{Cl}_{2} / \mathrm{EtOH}$ during the washing step, following the picrate binding on the resin was tested, protocol 3 . The enhanced solvation of the picrate-resin in this mixed solvent ( $42 \%$ against $6 \%$ in $\mathrm{CH}_{2} \mathrm{Cl}_{2}$, Table 2 ), due to its higher polarity [(AN+DN) value of 45.3, Table 2], seemed to ensure the removal of the excess picric acid from the resin, allowing the correct ammonium group quantification with this protocol $\left(0.363 \mathrm{mmol} \mathrm{g}^{-1}\right)$. The final solvation test (protocol 4) was carried out in order to check the need of $\mathrm{CH}_{2} \mathrm{Cl}_{2}$ replacement for $\mathrm{CH}_{2} \mathrm{Cl}_{2} / \mathrm{DMF}$ mixture during the amine group TEA-neutralization process in the first step of the picric acid method. The reason was the lower swelling of this model peptidyl-resin in TEA solution in $\mathrm{CH}_{2} \mathrm{Cl}_{2}$ rather than in DMF $(52 \%$ against $80 \%$ of bead swelling) measured previously ${ }^{5}$. However, no difference in the amine group quantification between these last two protocols (3 and 4) was observed, thus stressing that in this case, the small difference in swelling mentioned between these two solvent systems during the TEA treatment was not sufficient to affect the final result.

The validity of the use of the $(\mathrm{AN}+\mathrm{DN})$ term as a novel solvent polarity scale has been previously demonstrated by investigating the interaction (solvation) of different peptidyl-

Table 1. Comparative picric acid monitoring of ING-BHAR $\left(2.6 \mathrm{mmol} \mathrm{g}^{-1}\right)$ with different solvating protocols.

\begin{tabular}{|c|c|c|c|c|}
\hline \multirow[b]{2}{*}{ Step } & \multicolumn{4}{|c|}{ Protocol } \\
\hline & 1 & 2 & 3 & 4 \\
\hline Deprotonation & $\begin{array}{c}2 \times 5 \mathrm{~min} \\
\mathrm{TEA} / \mathrm{CH}_{2} \mathrm{Cl}_{2}\end{array}$ & $\begin{array}{c}2 \times 5 \mathrm{~min} \\
\mathrm{TEA} / \mathrm{CH}_{2} \mathrm{Cl}_{2}\end{array}$ & $\begin{array}{c}2 \times 5 \mathrm{~min} \\
\mathrm{TEA} / \mathrm{CH}_{2} \mathrm{Cl}_{2}\end{array}$ & $\begin{array}{c}2 \times 5 \mathrm{~min} \\
\text { TEA/DMF }\end{array}$ \\
\hline Washing & $\begin{array}{c}6 \times 2 \mathrm{~min} \\
\mathrm{CH}_{2} \mathrm{Cl}_{2}\end{array}$ & $\begin{array}{c}6 \times 2 \mathrm{~min} \\
\mathrm{CH}_{2} \mathrm{Cl}_{2}\end{array}$ & $\begin{array}{c}6 \times 2 \mathrm{~min} \\
\mathrm{CH}_{2} \mathrm{Cl}_{2}\end{array}$ & $\begin{array}{c}6 \times 2 \mathrm{~min} \\
\mathrm{CH}_{2} \mathrm{Cl}_{2}\end{array}$ \\
\hline $\begin{array}{l}\text { Picrate } \\
\text { binding }\end{array}$ & $\begin{array}{c}3 \times 5 \mathrm{~min} \\
0.08 \mathrm{~mol} \mathrm{~L}^{-1} \text { picric } \\
\text { acid in } \mathrm{CH}_{2} \mathrm{Cl}_{2}\end{array}$ & $\begin{array}{c}3 \times 5 \mathrm{~min} \\
0.08 \mathrm{~mol} \mathrm{~L}^{-1} \text { picric } \\
\text { acid in } \mathrm{CH}_{2} \mathrm{Cl}_{2} / \mathrm{DMF}\end{array}$ & $\begin{array}{c}3 \times 5 \mathrm{~min} \\
0.08 \mathrm{~mol} \mathrm{~L}^{-1} \text { picric } \\
\text { acid in } \mathrm{CH}_{2} \mathrm{Cl}_{2} / \mathrm{DMF}\end{array}$ & $\begin{array}{c}3 \times 5 \mathrm{~min} \\
0.08 \mathrm{~mol} \mathrm{~L}^{-1} \text { picric } \\
\text { acid in } \mathrm{CH}_{2} \mathrm{Cl}_{2} / \mathrm{DMF}\end{array}$ \\
\hline Washing & $\begin{array}{c}10 \times 2 \mathrm{~min} \\
\mathrm{CH}_{2} \mathrm{Cl}_{2}\end{array}$ & $\begin{array}{c}10 \times 2 \mathrm{~min} \\
\mathrm{CH}_{2} \mathrm{Cl}_{2}\end{array}$ & $\begin{array}{c}10 \times 2 \text { min } \\
\mathrm{CH}_{2} \mathrm{Cl}_{2} / \mathrm{EtOH}\end{array}$ & $\begin{array}{c}10 \times 2 \text { min } \\
\mathrm{CH}_{2} \mathrm{Cl}_{2} / \mathrm{EtOH}\end{array}$ \\
\hline $\begin{array}{l}\text { Elution of the } \\
\text { bound picrate }\end{array}$ & $\begin{array}{c}2 \times 10 \mathrm{~min} \\
\mathrm{TEA} / \mathrm{CH}_{2} \mathrm{Cl}_{2}\end{array}$ & $\begin{array}{c}2 \times 10 \mathrm{~min} \\
\mathrm{TEA} / \mathrm{CH}_{2} \mathrm{Cl}_{2}\end{array}$ & $\begin{array}{c}2 \times 10 \mathrm{~min} \\
\mathrm{TEA} / \mathrm{CH}_{2} \mathrm{Cl}_{2}\end{array}$ & $\begin{array}{c}2 \times 10 \mathrm{~min} \\
\mathrm{TEA} / \mathrm{CH}_{2} \mathrm{Cl}_{2}\end{array}$ \\
\hline Washing & $\begin{array}{c}2 \times 2 \mathrm{~min} \\
\mathrm{CH}_{2} \mathrm{Cl}_{2}\end{array}$ & $\begin{array}{c}2 \times 2 \mathrm{~min} \\
\mathrm{CH}_{2} \mathrm{Cl}_{2}\end{array}$ & $\begin{array}{c}2 \times 2 \mathrm{~min} \\
\mathrm{CH}_{2} \mathrm{Cl}_{2}\end{array}$ & $\begin{array}{c}2 \times 2 \mathrm{~min} \\
\mathrm{CH}_{2} \mathrm{Cl}_{2}\end{array}$ \\
\hline $\begin{array}{l}\text { Amine group } \\
(\mathrm{mmol})\end{array}$ & 0.108 & 0.392 & 0.363 & 0.362 \\
\hline
\end{tabular}

Table 2. Swelling degree of ING-BHAR $\left(2.6 \mathrm{mmol} \mathrm{g}^{-1}\right)$ on unprotonated and protonated (picrate salt) forms.

\begin{tabular}{|c|c|c|c|c|c|c|c|}
\hline \multicolumn{2}{|l|}{ Solvent } & \multicolumn{2}{|c|}{$\mathrm{CH}_{2} \mathrm{Cl}_{2}$} & \multicolumn{2}{|c|}{$\mathrm{CH}_{2} \mathrm{Cl}_{2} / \mathrm{DMF}$} & \multicolumn{2}{|c|}{$\mathrm{CH}_{2} \mathrm{Cl}_{2} / \mathrm{EtOH}$} \\
\hline $\begin{array}{l}\text { Polarity } \\
(\mathrm{AN}+\mathrm{DN})\end{array}$ & & \multicolumn{2}{|c|}{21.4} & \multicolumn{2}{|c|}{32.0} & \multicolumn{2}{|c|}{45.3} \\
\hline Amine group & $\begin{array}{l}\text { Diam. } \\
\text { dry bead } \\
(\mu \mathrm{m})\end{array}$ & $\begin{array}{c}\text { Diam. } \\
\text { Swollen bead } \\
(\mu \mathrm{m})\end{array}$ & $\begin{array}{l}\text { Vol. Solvent } \\
\text { within bead } \\
\qquad(\%)^{\mathrm{a}}\end{array}$ & $\begin{array}{c}\text { Diam. } \\
\text { swollen bead } \\
(\mu \mathrm{m})\end{array}$ & $\begin{array}{c}\text { Vol. solvent } \\
\text { within bead } \\
\qquad \%)^{\mathrm{a}}\end{array}$ & $\begin{array}{c}\text { Diam. } \\
\text { swollen bead } \\
(\mu \mathrm{m})\end{array}$ & $\begin{array}{c}\text { Vol. solvent } \\
\text { within bead } \\
(\%)^{\mathrm{a}}\end{array}$ \\
\hline $\mathrm{NH}_{2}$ & 79 & 89 & 31 & 131 & 78 & 100 & 52 \\
\hline $\mathrm{NH}_{3}^{+}$Picrate $^{-}$ & 88 & 90 & 06 & 135 & 73 & 94 & 42 \\
\hline
\end{tabular}

a [(swollen volume - dry volume )/swollen volume] x 100 . 
resins, taken deliberately as models of complex solutes, with several solvent systems. ${ }^{5}$ Due to its amphoteric character given by the summation of Lewis acid and Lewis base in a single term, this polarity parameter showed better correlation with the solvation degree of all peptidyl-resin assayed than other solvent properties known so far as the dielectric constant, the Dimroth-Reichardt ${ }^{\prime} \mathrm{E}_{\mathrm{T}}(30)^{23}$ and $\mathrm{AN}$ and DN, isolated. Although not shown in that work, several other relevant solvent empirical properties such as Hildebrand's $\delta$ solubility parameter ${ }^{24}$, Kamlet-Taft's $\pi^{* 25}$ parameter and the Swain's ${ }^{26}$ acidity $(\alpha)$ and basicity $(\beta)$ scales that are equivalent to the $\mathrm{AN}$ and $\mathrm{DN}$ numbers, respectively, were also considered but none of them presented improved correlation with solvation data of peptidyl-resins, if compared with the proposed $(\mathrm{AN}+\mathrm{DN})$ number. We are currently examining other types of solvent-solute interactions using this amphoteric solvent parameter and the present work represents an example of its application as a polarity parameter for helping evaluate failures on the picric acid procedure.

To our knowledge, the present study represents the first quantitative solvation approach applied to a resin-supported analytical technique. The results confirmed the critical role of the solvation property of the polymeric matrix in an important procedure used in biochemistry and polymer chemistry areas. We demonstrated that, due to the poor solvation effect associated with conformational restraints of the resin-bound peptide chains, the original picric acid method, introduced almost three decades ago, is not capable of measuring correctly the amine group content of some peptide-loaded resins. It is demonstrated in the present work that this limitation is due basically to strong shrinking of beads in apolar condition which is often observed ${ }^{3,5}$ with resins containing strong aggregating and/ or polar sequences. Moreover, in contrast to the belief that the main problem in this method might be related to insufficient removal of excess picric acid used ${ }^{16}$, the present report emphasizes instead that efficient resin solvation at the picrate-binding step is essential for the accuracy of this analytical method, considered superior to the ninhydrin procedure. ${ }^{27}$

In summary, the present findings exposed relevant shortcomings in this well-known resin-supported analytical method. Care should be therefore geared towards any procedures or reactions carried out throughout resin matrix including for instance, not only the synthesis of other macromolecules such as oligonucleotides ${ }^{28}$, but those involved in combinatory chemistry ${ }^{29}$ and solidphase organic synthesis ${ }^{30}$ strategies, intensively applied as examples of modern polymer application in chemical and biological fields.

\section{Acknowledgements}

This work was partially supported by the Brazilian Financing Agencies FAPESP, CNPq, FINEP and CAPES.

\section{References}

1. Barany, G.; Merrifield, R. B. The Peptides; Academic Press; New York, 1980, vol.2, p.1.

2. Fields, G. B.; Noble, R. L. Int. J. Peptide Protein Res. 1990, $35,161$.

3. Kent, S. B. H. Ann. Rev. Biochem. 1988, 57, 957.

4. Oliveira, E.; Miranda, A.; Albericio, F.; Andreu, D.; Paiva, A. C. M.; Nakaie, C. R.; Tominaga, M. Int. J. Peptide Protein Res. 1997, 49, 300.

5. Cilli, E. M.; Oliveira, E.; Marchetto, R.; Nakaie, C. R. J. Org. Chem. 1996, 61, 8992.

6. Gutmann, V. The Donor-Acceptor Approach to Molecular Interaction.; Plenum Press; New York, 1978.

7. Henkel, B.; Bayer, E. J. Pept. Res. 1998, 4, 461.

8. Kiefer, P. A. J. Org. Chem. 1996, 61, 1558.

9. Cilli, E. M.; Marchetto, R.; Schreier, S.; Nakaie, C. R. Tetrahedron Lett. 1997, 38, 517.

10. Cilli, E. M.; Marchetto, R.; Schreier, S.; Nakaie, C. R. J. Org. Chem. 1999, 64, 9118.

11. Marchetto, R.; Schreier, S.; Nakaie, C. R. J. Am. Chem. Soc. 1993, 115, 11042.

12. Pietta, P. G.; Cavallo, P. F.; Takahashi, K.; Marshall, G. R. J. Org. Chem. 1974, 39, 44.

13. Carvalho, R. S. H.; Tersariol, I. L. S.; Nader, H. B.; Nakaie, C. R. Anal. Chim. Acta 2000, 403, 205.

14. Carvalho, R. S. H., Straus, A.H., Takahashi, H.K., Nakaie, C. R. Chromatographia (in press).

15. Gisin, B. Anal. Chim. Acta 1972, 58, 248.

16. Hancock, W.S.; Battersby, J.E.; Harding, D.R.K. Anal. Biochem. 1975, 69, 497.

17. Hodges, R. S.; Merrifield, R. B. Anal. Biochem. 1975, 65, 241.

18. Marchetto, R.; Etchegaray, A.; Nakaie, C. R. J. Braz. Chem. Soc. 1992, 3, 30.

19. Kaiser, E.; Colescott, R. L.; Bossinger, C. D.; Cook, P. I. Anal. Biochem. 1970, 34, 595.

20. Irani, R. R.; Callis, C. F.; Particle Size: Measurement, Interpretation and Application; Wiley, New York, 1963.

21. Hancock, W. S.; Prescott, D. J.; Vagelos, P. R.; Marshall, G. R. J. Org. Chem. 1973, 38, 774.

22. Meek, J. L.; Rossetti, Z. L. J. Chromatogr. 1981, 211,15 .

23. Dimrot D. B.; Reichardt, C.; Siepmann, T.; Bohlman, F. Justus Liebigs Ann. Chem. 1963, 661, 1. 
24. Hildebrand, J. H. Chem. Rev. 1949, 44, 37.

25. Kamlet, M. J.; Abboud, J. L. M.; Abraham, M. H.; Taft, R. W. J. J. Org. Chem. 1983, 48, 2877.

26. Swain, C. G., Swain, M. S.; Powell, A. L.; Alunni, S. J. Am. Chem. Soc. 1983, 105, 502.

27. Arad, O.; Houghten, R. A. Peptide Research 1990, 3, 42.
28. Letsinger, R. L.; Finnan, J. L.; Heavner, G. A.; Lunsford, W. B. J. Am. Chem. Soc. 1975, 85, 3278.

29. Jung, G.; Beck-Sickinger, A. G. Angew. Chem. , Int. Ed. Engl. 1992, 31, 367.

30. Han, H.; Wolfe, M. M.; Brenner, S.; Janda, K. D. Proc. Natl. Acad. Sci. USA, 1995, 92, 6419.

Received: November 22, 1999 Published on the web: September 15, 2000 FAPESP helped in meeting the publication costs of this article. 